\title{
COMPARISON OF LITHOLOGIC MAPPING WITH ASTER AND HYPERION DATA: A CASE STUDY IN THE NORTHERN OF ZARA (SIVAS), TURKEY
}

DOI: http://dx.doi.org/10.18509/GBP.2018.19

UDC: 528.9:553.2(560)

\author{
Oktay Canbaz ${ }^{1}$ \\ Rutkay Atun ${ }^{2}$ \\ Onder Gursoy ${ }^{2}$ \\ Ahmet Gokce ${ }^{1}$ \\ Tarik Turk ${ }^{2}$ \\ Anil Can Birdal ${ }^{2}$ \\ ${ }^{1}$ Cumhuriyet University, Geological Engineering Department, Turkey \\ ${ }^{2}$ Cumhuriyet University, Geomatics Engineering Department, Turkey
}

\begin{abstract}
Hydrothermal alteration is one of the most important steps in the exploration of precious ore deposits. In this study, it is aimed to detect the hydrothermal alteration areas and mineral contents they preserve with ASTER and Hyperion satellite images and compare the obtained results. Because of the presence of intensive hydrothermal alteration and poor vegetation, the area which is located at the northern part of Zara district of Sivas Province has been chosen as the study area. Contact zones of Argillic (Kaolinite, illite), phyllic (serisite, muscovite) and propylitic (chlorite, calsite, epidote) alteration areas were detected with field studies, petrographic and geochemical investigations. The spectral signatures of hydrothermal minerals were measured via ASD spectroradiometer from the representative samples belonging to hydrothermal alteration study areas. According to the results, obtaining the hydrothermal alteration maps from ASTER and Hyperion satellite data are in coincide with the geological map.
\end{abstract}

Keywords: Hydrothermal alteration, ASTER, Hyperion, Zara, Sivas

\section{INTRODUCTION}

In recent years, remote sensing methods have been used widely in determining geological characteristics such as geological mapping, lineaments and hydrothermal alteration [1], [2], [3], [4], [5], [6], [7], [8], [9], [10]. This study was carried out as field and laboratory studies on the hydrothermal alterations which is located to the northern of Zara district of Sivas province.

Hydrothermal alteration investigation is one of the ore deposits research and explorations steps. Especially, to determine the no discovered mineral enrichments is quite important process. The host rocks associated with mineralization show physical and chemical changes (such as color, texture) with the effect of atmospheric and hydrothermal fluids. These transformations can be detected by field studies and satellite images.

In this study, the alteration image results of ASTER and Hyperion satellite images will be compared with prepared geology map. 


\section{GEOLOGY}

The study area is located between north of İzmir-Ankara-Erzincan Suture Zone and south of Eastern Pontide (figure 1).

Paleozoic Akdağmadeni/Tokat Metamorphics, Mesozoic Refahiye Complex, MiddleUpper Eocene Karataş Volcanics, Lutesian (Upper Eocene) Kösedağ Syenite are outcrop in the study area and Miocene-Quaternary volcanic and sedimentary rocks are overlain them as unconformably (figure 1b). Karataş Volcanics have basalt, basaltic trachyandesite, trachyte, trachyandesite and andesite components which show greenishblack colors and the rocks contain intense hydrothermal alteration. Kösedağ Syenite is dominated by feldspar phenocryst and is pinkish color.

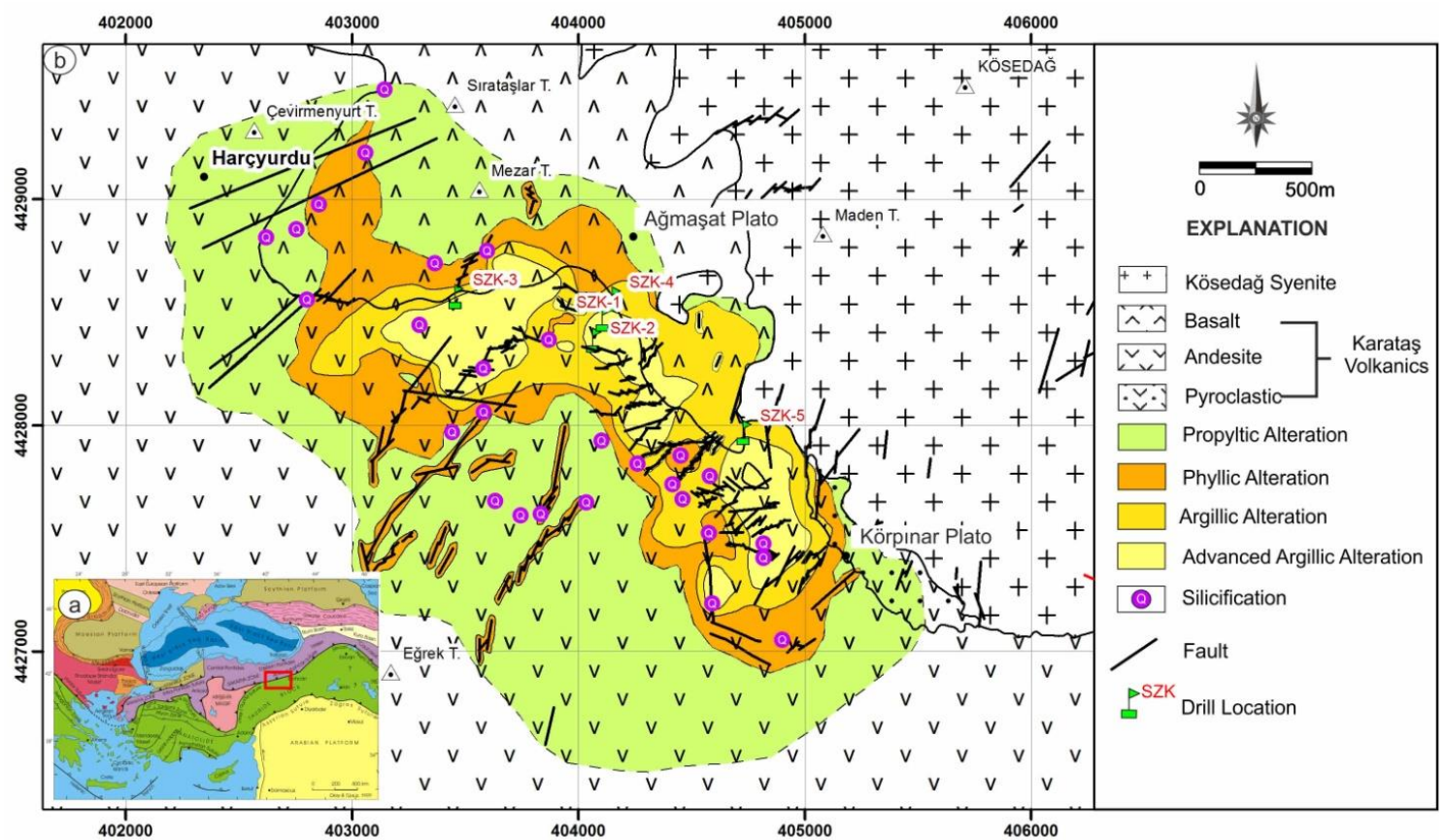

Figure 1. a) The neotectonic map of Turkey [11]. b) Geological map of the study area

\section{MATERIAL AND METHOD}

In the scope of the study, Hyperion EO 1 and ASTER satellites were used as satellite images. Hyperion was launched in 2000 and is known to be the first space based hyperspectral sensor [1]. The Hyperion sensor has a total of 242 bands and 16 bit radiometric resolution and a spatial resolution of 30 meters. Bad bands were removed from the image [12]. ASTER 3 VNIR, 6 SWIR and 5 TIR have a total of 14 bands with spatial resolution of 15, 30 and 90 meters respectively [2]. Radiometric and atmospheric corrections of ASTER and Hyperion satellite images were performed by using various programs.

The representative rock samples collected during the field studies were defined by petrography, geochemistry and XRD analyses in the laboratories. According to results, the detected hydrothermal alteration zones (propyllitic, phyllic, argillic) are shown on the geological map (Figure 1b). The spectral signatures obtained by ASD spectroradiometer from the representative hydrothermally altered rocks were resampled at the ASTER and 
Hyperion band intervals. Matched filtering method which is one of spectral classification methods was used in image processing [13].

\section{RESULTS AND DISCUSSION}

As a result of the study, it has been understood that the use of Hyperion and ASTER satellite sensors in the production of lithology maps are highly effective. Although both sensors are no longer provide up-to-date data, lithology maps using archival data can be made using these two sensors. According to the applied spectral classification, ASTER image has detected less variety in the lithology maps than Hyperion image. However, since Hyperion is not widely available anywhere, it has been understood that ASTER image can be used effectively in lithological classification. Preprocessing steps such as radiometric, atmospheric and geometric correction operations of remote sensing images used in such studies should be definitely be done. Converting the digital numbers of the images to reflectance for integrating the satellite images with the spectroradiometer data will enhance the accuracy of the spectral classification with a precise re-sampling of the satellite image bandwidth used in classification. In order to test the accuracy of spectral classification, geological data that were produced previously was used. When 1: 25000 scale of geological maps are analyzed, the MF values obtained in both results overlap with these lithology maps.

\section{REFERENCES}

[1] Faroog S \& Govil H. Mapping Regolith and Gossan for mineral exploration in the Eastern Kumaon Himalaya, India using Hyperion data and object oriented image classification, Advance in Space Research, vol. 53, pp 1676-1685, 2014.

[2] Amer R, El Mezayen A \& Hasanein M. ASTER spectral analysis for alteration minerals associated with gold mineralization. Ore Geology Reviews, vol. 75, pp 239-251, 2016.

[3] Hosseinjani Zadeh M, Tangestani MH, Roldan FV \& Yusta I. Sub-pixel mineral mapping of a porphyry copper belt using EO-1 Hyperion data. Advances in Space Research, vol. 53(3), pp 440-451, 2014.

[4] Kumar C, Shetty A, Raval S, Sharma R, \& Ray PKC. Lithological Discrimination and Mapping using ASTER SWIR Data in the Udaipur area of Rajasthan, India. Procedia Earth and Planetary Science, vol. 11, pp 180-188, 2015.

[5] Liu L, Zhou J, Han L \& Xu X. Mineral mapping and ore prospecting using Landsat TM and Hyperion data, Wushitala, Xinjiang, northwestern China. Ore Geology Reviews, vol. 81, pp 280295, 2017.

[6] Pour AB \& Hashim M. The application of ASTER remote sensing data to porphyry copper and epithermal gold deposits. Ore Geology Reviews, vol. 44, pp 1-9, 2012.

[7] Pournamdari M, Hashim M \& Pour AB. Spectral transformation of ASTER and Landsat TM bands for lithological mapping of Soghan ophiolite complex, south Iran. Advances in Space Research, vol. 54(4), pp 694-709, 2014.

[8] Canbaz O, Gürsoy Ö \& Gökçe A. Determination of hydrothermal alteration areas by Aster satellite images: Ağmaşat Plato-Zara (Sivas) / Turkey Sample. Cumhuriyet Science Journal, vol. 38(3), pp 419-426, 2017.

[9] Gürsoy Ö, Kaya Ş, Çakır Z, Tatar O \& Canbaz O. Determining lateral offsets of rocks along the eastern part of the North Anatolian Fault Zone (Turkey) using spectral classification of 
satellite images and field measurements. Geomatics, Natural Hazards and Risk, vol. 8(2), pp 1276-1288, 2017.

[10] Gürsoy Ö, Canbaz O, Gökçe A \& Atun R. Spectral classification in lithological mapping a case study of matched filtering. Cumhuriyet Science Journal, vol. 38(4), pp 731-737, 2017.

[11] Okay AI \& Tüysüz O. Tethyan sutures of northern Turkey. Geological Society, London, Special Publications, vol. 156, pp 475-515, 1999.

[12] Magendran T\& Sanjeevi S. Hyperion image analysis and linear spectral unmixing to evaluatethe grades of iron ores in parts of Noamundi, Eastern India. International Journal of Applied Earth Observation and Geoinformation, vol. 26, pp 413-426, 2014.

[13] Harsanyi J \& Chang C. Hyperspectral image dimensionality reduction and pixel classification: An orthogonal subspace projection approach. IEEE Transactions on Geoscience and Remote Sensing, vol. 32(4), pp 779-785, 1994. 